\title{
MEANING AND PROBLEMS OF IDENTIFICATION OF BETA COEFFICIENT WHEN VALUING FINANCIAL INSTITUTIONS
}

\section{Milan Hrdý, Markéta Pláničková*}

\begin{abstract}
The aim of this article consists in the analysis of the beta coefficient presented in different areas for three types of financial institutions: banks, investment banks and life insurance companies. In the final evaluation, we analyse whether the beta coefficient has a high tendency to reach number one and whether there is a relatively stabilized position of the beta coefficient different from one for a certain period and a certain financial institution on a certain market and whether it is possible to avoid a relatively complicated process of beta coefficient identification in income valuation. For that reason, the analysis of the five-year beta coefficient in the years 2000-2014 was performed for the USA, developed European, emerging European, developed Asian and emerging Asian regions. The analysis proved that the beta coefficient values are lower than the "magic one", meaning that using a beta coefficient equal to one is possible only in some specific cases. Also, stability of the beta coefficient with some permitted deviation was identified only for some financial institutions and for some markets, for example 0.6 for banks on the developed Asian market and 0.35 on the US market.
\end{abstract}

Keywords: valuation, beta coefficient, analysis, financial institutions

JEL Classification: G21, G22, G32

\section{Introduction}

The valuation of financial institutions such as banks, savings banks, insurance companies, investment companies, investment funds, pension companies, securities dealers, etc., is a very interesting topic, developed only in the last few years. The basic methodological approach in the individual valuation processes is based on a projection of the specifics of the relevant institution's valuation into general and very sophisticated processes for enterprises. Financial institutions can be seen as specific business entities that operate with funds comparable to traditional enterprises in a significantly greater extent, providing financial services, investing their and their clients' money. Some of them also provide loans. Equally significant is the fact that these institutions use debt in abundance in their business, which is entrusted from their clients, and in the case of its successful appreciation they share their revenue with clients. If we want to adequately capture the future potential of a valuated financial institution, in most cases, we must use the income approach as in the case of traditional enterprises. This valuation is based largely on removable net income, dividend

Milan Hrdý, University of Economics, Prague, Faculty of Finance and Accounting, Prague, Czech Republic (Milan.hrdy@vse.cz);

Markéta Pláničková, University of Economics, Prague, Faculty of Finance and Accounting, Prague, Czech Republic (marketa.planickova@vse.cz). 
potential or free cash flow to the owners (FCFE - Free Cash Flow to Equity). In any case, it will be necessary to identify the discount interest rate for discounting these future effects. When identifying the discount interest rate based on the capital market line, we run into the problem of identifying the beta coefficient. Some theoretical views (e.g., Damodaran, 2009; Hrdý, 2012) try to dispute the possibility of using the fact that financial institutions usually copy market portfolio development, so it would therefore be possible to apply the beta coefficient equal to one for their valuation and thus avoid relatively complicated calculations. Besides this fact, it is also possible to explore whether the beta coefficient is relatively stabilized for a certain period and a selected financial institution on a certain market. If it is possible, then a lot of complicated efforts can be reduced in the valuation practice and some important contribution to financial theory can be identified.

The considerations mentioned above lead to the generating of the basic objective of this paper, which consists in the analysis of the beta coefficient presented in different areas for three financial institutions: banks, investment banks and life insurance companies; in final evaluation, we analyse whether the beta coefficient has a high tendency to reach number one and whether there is a relatively stabilized position of the beta coefficient different from one for a certain period and a certain financial institution on a certain market. The question is if it is possible to avoid a relatively complicated process of beta coefficient identification in income valuation of a specific financial institution. A hypothesis can be stated that the beta coefficient values will be highly volatile, can be equal to one only in some specific cases and that the stable position of the beta coefficient is only in some periods for some specific financial institutions on some specific markets. For meeting the objective and for a confirmation or refutation of the hypothesis, we will use the method of analysing the available data from the S\&P Capital IQ database, while the results obtained will then be synthesized into appropriate conclusions useful in both theory and practice of financial institution valuation. This analysis and the subsequent synthesis of the obtained information is based not only on a verbal description, but also on some basic statistical assessment in each financial institution category on the selected market. The main contribution to financial theory and practice lies in the analysis of the development and the extent of the volatility of the beta coefficient in different areas for different types of financial institutions and in the identification of the possibility to use a stable value of this coefficient instead of a relatively complicated process of identification of this coefficient in valuation practice. There is relatively little knowledge concerning the theory and practice of identification of the beta coefficient in the case of financial institution valuation. Despite this situation, however, it is necessary to present some theoretical and practical background before the analysis of the available data.

\section{Theoretical Background}

The issue of identification of the discount interest rate for income valuation of banks and other financial institutions in conditions of the Czech Republic has been resolved only in recent years, for example by Hrdý (2012) or by Hejduková (2010) or Pláničková (2014). This problem is also solved abroad to a very limited extent. Even in the two most famous publications dealing with valuation of banks and other financial institutions (Miller, 
1995; Rezaee, 2001), the specifics of determining the discount interest rate for the valuation of financial institutions are not analysed in depth. In chapters concerning the discount interest rate, the general procedures are validly described rather for traditional enterprises. On the other hand, some interesting insights can be found in the publications of Damodaran (2001, 2009), Hazel (1995) and Koller (2005). Because the identification of the average weighted costs of capital is not suitable for financial institution valuation, the cost of equity is recommended and three basic approaches known in the financial theory - the dividend growth model, the modular method and the capital market line - are analysed in the literature mentioned above. However, there are some theoretical and application problems that limit the use of these methods.

In the case of the dividend growth model, there is the problem whether it is better to use the current or the expected dividend. However, it is not necessary to analyse this approach, because there is no identification of the beta coefficient. The same situation concerning the beta coefficient occurs in the case of the modular method, which lies in the subsequent notice of full risk not only systematically, but also specifically. This method is elaborated for the purposes of traditional enterprises by Mařík (2007) and for the purposes of banks by Hrdý (2012).

If the capital market line is used, besides the beta coefficient identification, there is also a problem with the risk-free interest rate. There is a controversy about whether to use the interest rate from treasury bills, which are almost risk-free, but short-lasting, or the interest rate from long-term government bonds. Given that the valuation process of prosperous financial institutions is mostly concerned with the long-term time horizon of their future operation, it is necessary to incline towards long-term government bonds.

Regarding the beta coefficient, its identification is disproportionately complicated and requires access to market data. There is a variety of different recommended procedures (Mařík, 2007; Damodaran, 2001). Damodaran (2009) published research results regarding the average beta coefficients for each class of financial institutions depending on different territorial areas. These values are demonstrated in Table 1.

Table 1 | Beta Coefficients of Selected Financial Institutions

\begin{tabular}{|l|c|c|c|}
\hline Type of financial institution & USA & Europe & Emerging markets \\
\hline Large banking houses & 0.71 & 0.90 & 0.90 \\
\hline Small regional banks & 0.91 & 0.88 & 1.05 \\
\hline Investment banks & 1.50 & 1.55 & 1.90 \\
\hline Credit unions & 0.66 & 0.75 & 0.85 \\
\hline Brokerage investment firms & 1.37 & 1.25 & 1.50 \\
\hline Life insurance agencies & 1.17 & 1.20 & 1.10 \\
\hline Non-life insurance agencies & 0.91 & 0.95 & 0.90 \\
\hline
\end{tabular}

Source: Damodaran (2009) 
Some complementary information to Table 1 can be derived from the research by Stever (2007), which reveals that after subsequent regulatory changes, the beta coefficient of smaller banks approaches that of larger banks. Stever (2007) proved that not only the type of loans affects a bank's equity beta, after controlling for the loan sector, but also the size is still significant. Stever (2007) also proved that "small bank borrowers do not have higher asset betas". It is a consequence of the fact that small banks are able to secure the credit risk, but on the other hand with less variance of the costs in their bank portfolio. Stever's study was based on relatively older studies, for example Brooks et al. (1997), who examine "the mean and variance of bank equity betas as a means of gauging the risk of banks across different regulatory time periods" and also on Dickens and Philippatos (1994) and Allen and Wilhelm (1988). Findings by Stever (2007) were also confirmed by Chen et al. (2014), who analyse the consequences of financial crises on banks' behaviour.

When identifying the beta coefficient, it is necessary to respect some specifics of financial institutions. The business risk of a specific financial institution will be the key for adjusting the basic beta coefficient. Even from Table 1 it is quite clear that a key factor for the beta coefficient will be the level of risk of the specific financial institution's relevant activities. Investment activity is the relatively highest risk, so that investment banks, investment companies and funds will have the highest beta coefficient. This also reflects an undeniable fact often mentioned in some publications (Hrdý, 2005; Hrdý, 2012) that investment activity is also one of the most difficult activities to plan among financial institutions' activities, which must inevitably be reflected in the high volatility of the results obtained, followed by a higher value of the beta coefficient. Conversely, the lowest beta coefficient is demonstrated by credit unions, which are quite strongly bounded and limited by the possibilities of financial business and relatively strong regulation. Insurance agencies have the highest tendency towards the beta coefficient of one; life insurance agencies prove a slightly higher risk than non-life insurance agencies. Another interesting fact is that these institutions have a relatively low volatility in the relevant areas. The differences between the USA, Europe and emerging markets are minimal. Damodaran (2009) draws attention to the important question of the relationship between the beta coefficient and the expected growth rate $g$. Greater expected growth usually means a higher beta coefficient. In contrast, in stable developed banks, so-called maturity banks, according to Damodaran (2009) the beta coefficient is near to one. This "magic one" is often spoken about by experts from relevant expert institutions, who do not wish to be named for obvious reasons. The market bank stabilization supported by the regulated business, by the need to have a relevant license, and therefore by the problem to push such mature and stable banks out of market positions also contributes to the "magic one".

The beta coefficient for banks was identified according to Hrdý (2012) considering the specifics and facts mentioned above, as follows:

$$
\beta=\beta_{K} \times P+\beta_{I} \times(1-P)+R_{R}+R_{O},
$$


where:

$\beta$ final beta coefficient,

$\beta_{i}$ basic beta coefficient for investment activities,

$\beta_{k}$ basic beta coefficient for commercial activities,

$R_{R}$ risk premium from the bank's expected growth perspective,

$R_{O}$ risk premium of the area,

$P$ the share of non-investment activity in the bank's total revenues.

If the risk premium for Europe could be zero and there is no expected future growth, the equation could be adjusted in the following way:

$$
\beta=\beta_{K} \times P+\beta_{I} \times(1-P)
$$

However, this equation is not capable of eliminating the problem of identification of the beta coefficient for commercial and for investment activities.

Based on Damodaran (2009), Hrdý (2012) adjusted this equation in the following way:

$$
\beta=0.9 \times P+1.55 \times(1-P) .
$$

However, this approach is highly disputable, because Damodaran's data are relatively older and changes in values of the beta coefficient are evident. This fact is demonstrated in Table 2:

Table 2 | Beta Coefficients of Selected Banks in 2017

\begin{tabular}{|l|c|}
\hline Bank name & Beta coefficient (February 2017) \\
\hline Komerční banka, a.s. & 1.00 \\
\hline Erste Bank & 1.56 \\
\hline KBC, Bank Holding & 1.64 \\
\hline Unicredit Bank & 1.94 \\
\hline Deutsche Bank & 1.32 \\
\hline
\end{tabular}

Source: www.patria.cz

The table above shows that real-world European banks have relatively higher beta coefficients than Damodaran (2009) identified and that Komerční banka, a.s., is the only Czech bank to have a beta coefficient at the level of the so-called "magic one".

In comparison to Equation 2, we can mention the relatively old approach published by Blume (1975), where the identification of the beta coefficient is calculated as the sum of 1 and the observed beta, where the share of 1 is $33 \%$ and the share of the observed beta is $67 \%$.

Besides Damodaran (2009), also King (2009) offers some interesting information about the differences in beta coefficients between 1990-2000 and 2001-2009 in selected countries. These values are demonstrated in Table 3. 
Table 3 | Beta Coefficients of Global Banks in 1990-2000 and 2001-2009

\begin{tabular}{|l|c|c|}
\hline Country & Beta coefficient 1990-2000 & Beta coefficient 2001-2009 \\
\hline Canada & 1.0 & 0.6 \\
\hline France & 1.0 & 0.8 \\
\hline Germany & 0.9 & 0.7 \\
\hline Japan & 0.9 & 1.1 \\
\hline United Kingdom & 1.0 & 0.8 \\
\hline USA & 1.1 & 0.8 \\
\hline
\end{tabular}

Source: King (2009)

The above information confirms that the beta coefficient oscillates around the "magical one" and that a decrease in the beta coefficient occurs in practically all the countries mentioned.

Insurance agencies also have to work with different risks than traditional enterprises. The beta coefficient estimation can be based on historical beta calculated using regression analysis, on beta derived from comparable companies using the analogy method, or on an analysis of influencing factors. In general, it can be said that we can rely more on the historical beta in the case of large mature insurance agencies than in the case of traditional enterprises.

This approach is not useful for insurance agencies operating in the Czech Republic since their shares are publicly traded with one exception. It is preferable to derive the beta coefficient from comparable insurance agencies using the analogy method. Proper attention should be paid to the selection of comparable insurance agencies and it is very important to monitor and to take into consideration differences among them. Differences among insurance agencies operating in different countries may arise, inter alia, from differences in organisation and regulation of the insurance industry. In the case of expected changes in regulatory requirements, the risk for insurance agencies increases and this is reflected in a higher beta coefficient. Differences may also occur among insurance agencies operating in the same country. They can differ in the composition of services provided and trade volume. Differences in the expected insurance agency growth also count. It is expected that in a fast-growing insurance agency, the risk is higher and thus the beta coefficient is higher compared to a mature insurance company in a stable phase. Thus, the equity costs in the first stage of an insurance agency's life cycle are higher than in the stable phase (Pláničková, 2014).

When we use data from Table 1 and from the presumption of the beta coefficient being close to 1, we can accept the approach of Hrdý (2012) with the following calculation:

$$
\beta=\beta_{N} \times P+\beta_{Z} \times(1-P)+R_{R}+R_{O}
$$


where:

$\beta \quad$ final beta coefficient,

$\beta_{z} \quad$ basic beta coefficient for the life insurance sphere,

$\beta_{N} \quad$ basic beta coefficient for the non-life insurance sphere,

$R_{R}$ risk premium for the bank's expected growth,

$R_{O}$ risk premium of the area,

$P \quad$ the share of non-life insurance activities in the insurance agency's total revenues.

Assuming that the basic beta coefficient for life insurance agencies according to Damodaran (2009) is identified at 1.1 and the basic beta coefficient for non-life insurance agencies at 0.9 and assuming stable mature insurance agencies in Europe, we can modify the above Equation 4 in the following way:

$$
\beta=0.9 \times P+1.1 \times(1-P) .
$$

If the share of non-life and life insurance activities is the same, then it is possible to identify a beta coefficient equal to one.

According to Pláničková (2014), in the valuation of major mature insurance agencies we can rely on historical beta determined by using a regression based on the past comparing to traditional businesses, but always depending on the stability of the development of a particular insurance agency and the entire insurance sector. Since it is not possible to apply this approach in the Czech Republic, Pláničková (2014) states that "it is preferable to derive the beta using the analogy method from comparable insurance agencies". Due to the fact that debt is difficult to define in the case of commercial insurance agencies, it is more practical to work with indebtedness. If using the analogy method, the beta coefficient can be taken from comparable insurance agencies at their present debt and this beta can be directly applied to the insurance agency valuation. A risk-free interest rate and risk premium will be identified in a similar way as with the valuation of enterprises.

Some German authors, for example, Jähnchen (2009), prefer a method for the estimation of the beta coefficient for insurance agencies based on an analysis of affecting factors. This process is not based on the past development of share prices, but on the main risk factors affecting the enterprise, such as business risk, financial risk, dividend policy, company size, growth, degree of diversification, etc. There is also a significant influence of the insurance risk associated with underwriting, premium calculations, establishment of technical provisions and reinsurance in the insurance agencies, along with market risk representing the effect of volatility to the future investment value on the financial market within a financial position. This process is very heavy on the appraisal experience.

Finally, it can be said that the identification of the beta coefficient for financial institutions is a very complicated process and there is no undisputable process in financial theory to recommend. Financial practice does not show any evident conclusions about the development of the beta coefficient. Some researchers and tables show a relatively permanent decrease in the beta coefficient, but others show some increase; some researchers and tables show the possibility to use the magic one, while others disprove it. Also values 
according to different researchers are different. The beta coefficient can be identified by long-time observations that are very often not available, or with the aid of adjustment of US data to the conditions of a specific country, including the Czech Republic. So, it is meaningful to be aware of some empirical research that explores the volatility of the beta coefficient for banks, investment banks and life insurance agencies in different areas for a relatively long period of 15 years with the aim to answer the question whether a certain stable position of the beta coefficient for banks, investment banks or life insurance agencies can be identified and to use it instead of the relatively complicated procedure of beta coefficient identification.

\section{Practical Research - Empirical Study}

\subsection{Identification of methodology}

The empirical study is based on data for the period 2000-2014 from the S\&P Capital IQ database regarding traded financial institutions around the world. The analysis is processed as a combination of an appropriate type of financial institution and the relevant region. These relevant regions are as follows:

- USA,

- Europe - developed markets,

- Europe - emerging markets,

- Asia - developed markets,

- Asia - emerging markets.

The types of financial institutions are as follows:

- banks,

- investment banks,

- $\quad$ life insurance agencies.

The five-year beta coefficient, calculated on monthly return over five years, was tested. For the beta coefficient of individual financial institutions, a median will be quantified for each segment and year and its development will be further examined. A verbal analysis will be made, describing mainly the development and the volatility of the beta coefficients, including the identification whether the so-called "magic one" can be identified somewhere. Besides this verbal description, some statistical analysis is also carried out. The following was computed for every region and category. For $y$ in $\{2000, \ldots, 2014\}$, the authors take the time window from $y$ to the year 2014 and try to find the narrowest interval containing all the beta coefficients in the time window. The intervals are given by a centre point and a width. The values of width and the values of centre points were identified. The authors denote them as $w_{c, r, y}$ and for $m_{c, r y}$ the category $c$, region $r$ and starting year $y$. The computed values allow the following statement: "Beta coefficients in the category $c$ in the region $r$ fluctuate around $m_{c, r, y}$ with the maximum deviation of $w_{c, r y}$ in the years $y$ to 2014." 
A conditional formatting is set in the width tables: if the width is less than the allowed deviation of $\mathbf{0 . 1 5}$, the cell contents are printed in bold. This gives a quick overview of what statements could be proposed. The allowed deviation of 0.15 is chosen according to some accepted volatility in the beta coefficient identification process. This relative stability in the chosen interval enables us to use the average value of the beta coefficient in some selected regions as the beta coefficient for the practical valuation.

The data for the final analysis are elaborated from the database in the form of tables and charts in the following way:

\subsection{Analysis of Beta Coefficient Development for Banks}

Figure 1 | Beta Coefficient Development for Banks

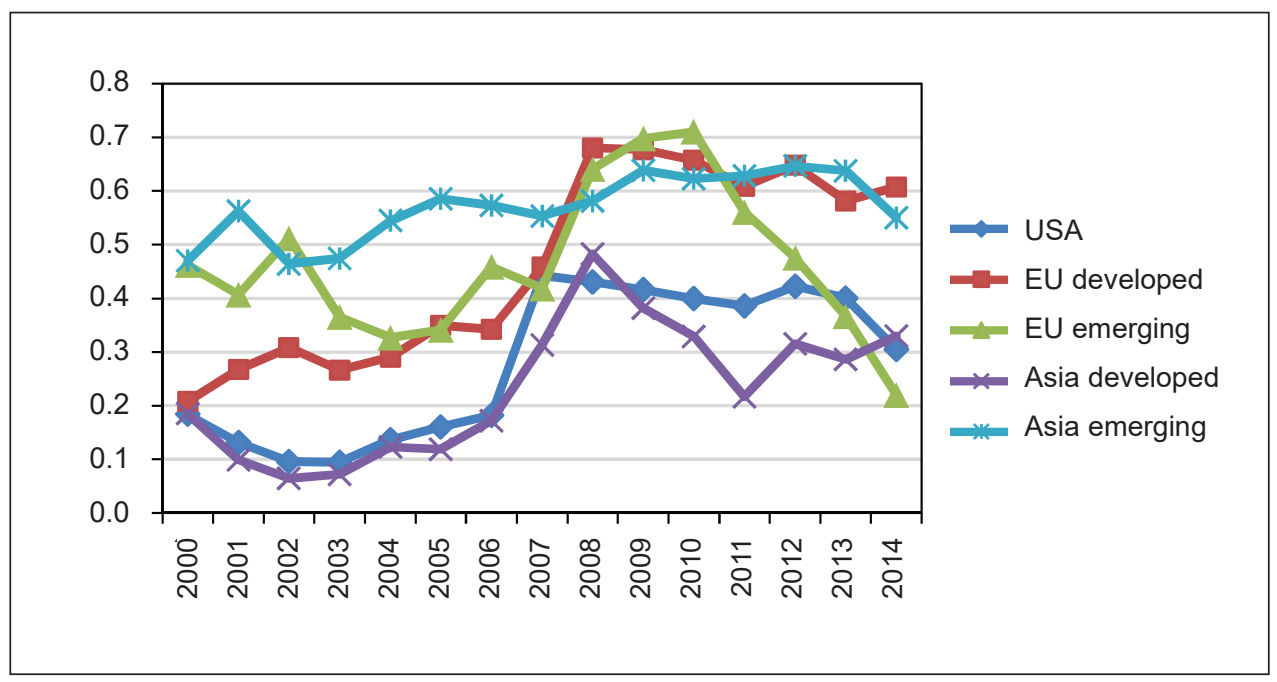

Source: S\&P Capital IQ's own production according to data from the S\&P Capital IQ database

Table 4 | Beta Coefficient Development for Banks

\begin{tabular}{|l|l|l|l|l|l|l|l|l|l|l|l|l|l|l|l|}
\hline Banks & $\mathbf{2 0 0 0}$ & $\mathbf{2 0 0 1}$ & $\mathbf{2 0 0 2}$ & $\mathbf{2 0 0 3}$ & $\mathbf{2 0 0 4}$ & $\mathbf{2 0 0 5}$ & $\mathbf{2 0 0 6}$ & $\mathbf{2 0 0 7}$ & $\mathbf{2 0 0 8}$ & $\mathbf{2 0 0 9}$ & $\mathbf{2 0 1 0}$ & $\mathbf{2 0 1 1}$ & $\mathbf{2 0 1 2}$ & $\mathbf{2 0 1 3}$ & $\mathbf{2 0 1 4}$ \\
\hline USA & 0.18 & 0.13 & 0.10 & 0.09 & 0.14 & 0.16 & 0.18 & 0.44 & 0.43 & 0.42 & 0.40 & 0.39 & 0.42 & 0.40 & 0.31 \\
\hline EU developed & 0.21 & 0.27 & 0.31 & 0.27 & 0.29 & 0.35 & 0.34 & 0.46 & 0.68 & 0.68 & 0.66 & 0.61 & 0.65 & 0.58 & 0.61 \\
\hline EU emerging & 0.46 & 0.41 & 0.51 & 0.37 & 0.33 & 0.34 & 0.46 & 0.42 & 0.64 & 0.70 & 0.71 & 0.56 & 0.48 & 0.37 & 0.22 \\
\hline Asia developed & 0.18 & 0.10 & 0.06 & 0.07 & 0.12 & 0.12 & 0.17 & 0.31 & 0.48 & 0.38 & 0.33 & 0.22 & 0.32 & 0.29 & 0.33 \\
\hline Asia emerging & 0.47 & 0.56 & 0.46 & 0.47 & 0.54 & 0.59 & 0.57 & 0.55 & 0.58 & 0.64 & 0.62 & 0.63 & 0.65 & 0.64 & 0.55 \\
\hline
\end{tabular}

Source: S\&P Capital IQ's own production according to data from the S\&P Capital IQ database 
The figure above shows that the beta coefficient development in the USA has been relatively stabilized since 2007 and it oscillates around the value of 0.4 with a slight decrease in the last year of the study period. This value of the beta coefficient was achieved after a significant increase in the times of economic and financial crisis; the values had been at 0.2 before the crisis. This confirms the fact that US commercial banks without investment activities that operate on a stable market show steady risk values and future removable net income and their profits are also relatively easy to plan.

EU banks operating on developed markets had values oscillating around 0.6 in recent years. They achieved this value in 2008 from substantially lower numbers, which was caused, among other things, by the effects of the economic and later financial crisis. It is thus clear that it would be possible to use these values for the purpose of valuation for both sectors in a simplified way.

Quite the opposite situation is on the emerging EU markets, where the volatility is very strong, and it is almost impossible to identify any trend. From 2009 to 2014, there is a serious decline in the beta coefficient value from 0.7 to 0.2 , which could be due, among other reasons, to the fact that banks in the region are often subsidiaries of banks from developed EU markets with a better financial condition and without a greater share of toxic assets. This is particularly true regarding banks in the Czech Republic.

The beta coefficients of emerging markets in Asia behave similarly as in the case of banks on developed EU markets, and oscillate around the value of 0.6 , demonstrating even the most stable values during the monitored years, which is certainly a very interesting finding. By contrast, the developed markets in Asia demonstrate a relatively high volatility in the range from 0.1 to 0.5 with a stabilization to 0.3 in the last three years. However, despite the relatively high volatility, the beta coefficient values are expectedly lower than in the case of the emerging markets.

Table 5 | Beta Coefficients for Banks - Centre Points

\begin{tabular}{|l|l|l|l|l|l|l|l|l|l|l|l|l|l|l|l|}
\hline Banks & $\mathbf{2 0 0 0}$ & $\mathbf{2 0 0 1}$ & $\mathbf{2 0 0 2}$ & $\mathbf{2 0 0 3}$ & $\mathbf{2 0 0 4}$ & $\mathbf{2 0 0 5}$ & $\mathbf{2 0 0 6}$ & $\mathbf{2 0 0 7}$ & $\mathbf{2 0 0 8}$ & $\mathbf{2 0 0 9}$ & $\mathbf{2 0 1 0}$ & $\mathbf{2 0 1 1}$ & $\mathbf{2 0 1 2}$ & $\mathbf{2 0 1 3}$ & $\mathbf{2 0 1 4}$ \\
\hline USA & 0.27 & 0.27 & 0.27 & 0.27 & 0.29 & 0.30 & 0.31 & 0.38 & 0.37 & 0.37 & 0.37 & 0.37 & 0.37 & 0.36 & 0.31 \\
\hline EU developed & 0.45 & 0.48 & 0.48 & 0.48 & 0.49 & 0.51 & 0.51 & 0.57 & 0.63 & 0.63 & 0.62 & 0.62 & 0.62 & 0.60 & 0.61 \\
\hline EU emerging & 0.47 & 0.47 & 0.47 & 0.47 & 0.47 & 0.47 & 0.47 & 0.47 & 0.47 & 0.47 & 0.47 & 0.39 & 0.35 & 0.30 & 0.22 \\
\hline Asia developed & 0.27 & 0.27 & 0.27 & 0.28 & 0.30 & 0.30 & 0.33 & 0.35 & 0.35 & 0.30 & 0.28 & 0.28 & 0.31 & 0.31 & 0.33 \\
\hline Asia emerging & 0.56 & 0.56 & 0.56 & 0.56 & 0.60 & 0.60 & 0.60 & 0.60 & 0.60 & 0.60 & 0.60 & 0.60 & 0.60 & 0.60 & 0.55 \\
\hline
\end{tabular}

Source: Own calculation.

Table 6 shows that for the allowed standard deviation of 0.15 , the development of beta coefficients is convenient in the case of Asia emerging and the USA from 2004, EU developed from 2007 and EU emerging from 2012. So, the usage of the market value instead of the relatively complicated identification is possible only in Asia emerging, EU developed 
and Asia developed. It is not possible in EU emerging. The recommended values of the beta coefficient can be used at the level of 0.6 on Asia emerging markets, 0.35 on USA markets, 0.6 on EU developed and 0.3 on Asia developed.

Table 6 | Beta Coefficients for Banks - Value of Width

\begin{tabular}{|l|c|c|c|c|c|c|c|c|c|c|c|c|c|c|c|}
\hline Banks & $\mathbf{2 0 0 0}$ & $\mathbf{2 0 0 1}$ & $\mathbf{2 0 0 2}$ & $\mathbf{2 0 0 3}$ & $\mathbf{2 0 0 4}$ & $\mathbf{2 0 0 5}$ & $\mathbf{2 0 0 6}$ & $\mathbf{2 0 0 7}$ & $\mathbf{2 0 0 8}$ & $\mathbf{2 0 0 9}$ & $\mathbf{2 0 1 0}$ & $\mathbf{2 0 1 1}$ & $\mathbf{2 0 1 2}$ & $\mathbf{2 0 1 3}$ & $\mathbf{2 0 1 4}$ \\
\hline USA & 0.18 & 0.18 & 0.18 & 0.18 & $\mathbf{0 . 1 5}$ & $\mathbf{0 . 1 4}$ & $\mathbf{0 . 1 3}$ & $\mathbf{0 . 0 7}$ & $\mathbf{0 . 0 6}$ & $\mathbf{0 . 0 6}$ & $\mathbf{0 . 0 6}$ & $\mathbf{0 . 0 6}$ & $\mathbf{0 . 0 6}$ & $\mathbf{0 . 0 5}$ & $\mathbf{0 . 0 0}$ \\
\hline EU developed & 0.24 & 0.21 & 0.21 & 0.21 & 0.20 & 0.17 & 0.17 & $\mathbf{0 . 1 1}$ & $\mathbf{0 . 0 5}$ & $\mathbf{0 . 0 5}$ & $\mathbf{0 . 0 4}$ & $\mathbf{0 . 0 4}$ & $\mathbf{0 . 0 4}$ & $\mathbf{0 . 0 2}$ & $\mathbf{0 . 0 0}$ \\
\hline EU emerging & 0.25 & 0.25 & 0.25 & 0.25 & 0.25 & 0.25 & 0.25 & 0.25 & 0.25 & 0.25 & 0.25 & 0.17 & $\mathbf{0 . 1 3}$ & $\mathbf{0 . 0 8}$ & $\mathbf{0 . 0 0}$ \\
\hline $\begin{array}{l}\text { Asia } \\
\text { developed }\end{array}$ & 0.21 & 0.21 & 0.21 & 0.21 & 0.18 & 0.18 & 0.16 & $\mathbf{0 . 1 3}$ & $\mathbf{0 . 1 3}$ & $\mathbf{0 . 0 8}$ & $\mathbf{0 . 0 6}$ & $\mathbf{0 . 0 6}$ & $\mathbf{0 . 0 2}$ & $\mathbf{0 . 0 2}$ & $\mathbf{0 . 0 0}$ \\
\hline Asia emerging & $\mathbf{0 . 1 0}$ & $\mathbf{0 . 1 0}$ & $\mathbf{0 . 1 0}$ & $\mathbf{0 . 0 9}$ & $\mathbf{0 . 0 6}$ & $\mathbf{0 . 0 5}$ & $\mathbf{0 . 0 5}$ & $\mathbf{0 . 0 5}$ & $\mathbf{0 . 0 5}$ & $\mathbf{0 . 0 5}$ & $\mathbf{0 . 0 5}$ & $\mathbf{0 . 0 5}$ & $\mathbf{0 . 0 5}$ & $\mathbf{0 . 0 5}$ & $\mathbf{0 . 0 0}$ \\
\hline
\end{tabular}

Source: Own calculation.

\subsection{Analysis of Beta Coefficient Development for Investment Banks}

Figure 2 | Beta Coefficient Development for Investment Banks

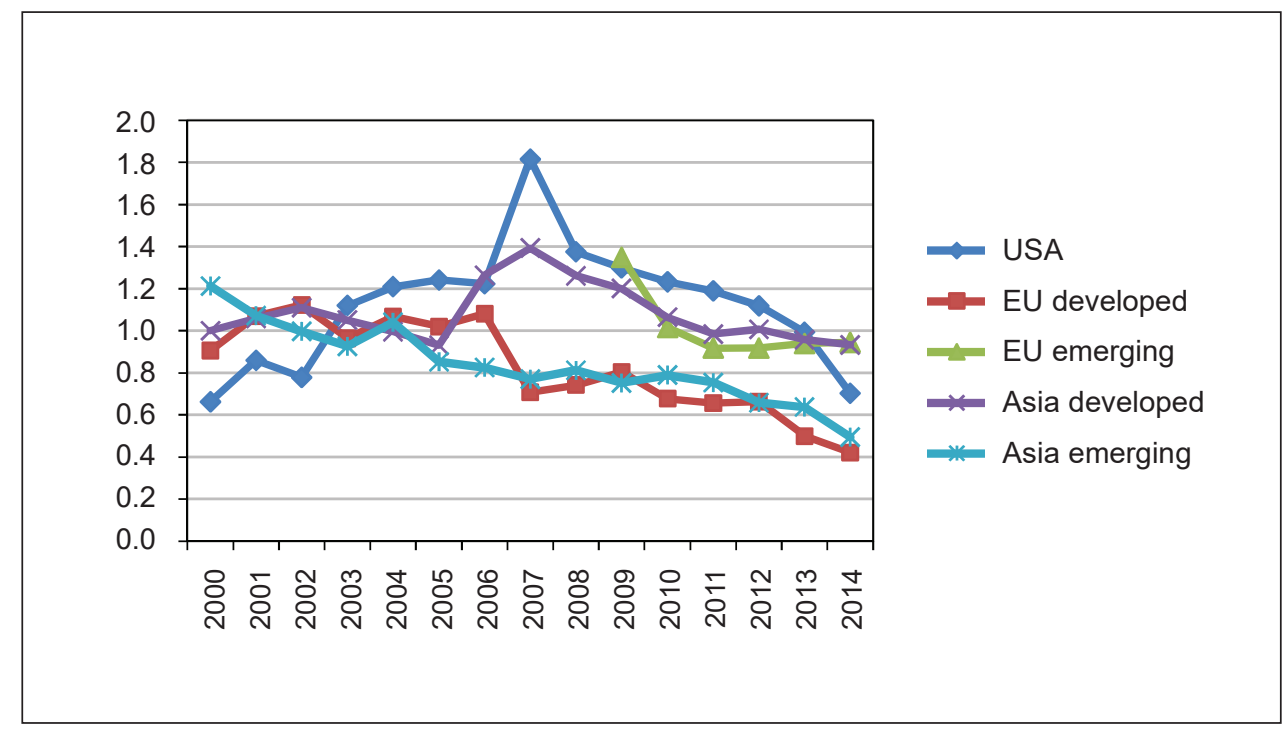

Source: S\&P Capital IQ's own production according to data from the S\&P Capital IQ database

Beta coefficient values are significantly higher for investment banks than in the case of commercial banks. Relatively the most stable downward trend is shown by banks on emerging Asian markets, where the beta coefficient has been steadily declining from 1.2 
in 2000 to a value of 0.6 , while in the crisis years it was oscillating around 0.8 . Similarly, a downward trend is shown in the beta coefficients on developed EU markets, albeit with a high degree of volatility, where the value decreases from 1.1 to 0.4 . This value is thus lower than in the case of traditional commercial banks, which is quite remarkable and difficult to understand. The only possible explanation could be the strong risk aversion during investment activity resulting from the negative consequences of the economic and financial crisis.

Table 7 | Beta Coefficient Development for Investment Banks

\begin{tabular}{|l|c|c|c|c|c|c|c|c|c|c|c|c|c|c|c|}
\hline Investment banks & $\mathbf{2 0 0 0}$ & $\mathbf{2 0 0 1}$ & $\mathbf{2 0 0 2}$ & $\mathbf{2 0 0 3}$ & $\mathbf{2 0 0 4}$ & $\mathbf{2 0 0 5}$ & $\mathbf{2 0 0 6}$ & $\mathbf{2 0 0 7}$ & $\mathbf{2 0 0 8}$ & $\mathbf{2 0 0 9}$ & $\mathbf{2 0 1 0}$ & $\mathbf{2 0 1 1}$ & $\mathbf{2 0 1 2}$ & $\mathbf{2 0 1 3}$ & $\mathbf{2 0 1 4}$ \\
\hline USA & 0.66 & 0.86 & 0.78 & 1.12 & 1.21 & 1.24 & 1.22 & 1.82 & 1.37 & 1.30 & 1.23 & 1.19 & 1.12 & 0.99 & 0.70 \\
\hline EU developed & 0.90 & 1.07 & 1.12 & 0.96 & 1.07 & 1.02 & 1.08 & 0.71 & 0.74 & 0.80 & 0.68 & 0.66 & 0.66 & 0.50 & 0.42 \\
\hline EU emerging & - & - & - & - & - & - & - & - & - & 1.35 & 1.02 & 0.92 & 0.92 & 0.94 & 0.94 \\
\hline Asia developed & 1.00 & 1.06 & 1.11 & 1.05 & 1.00 & 0.93 & 1.26 & 1.39 & 1.26 & 1.20 & 1.06 & 0.98 & 1.01 & 0.96 & 0.93 \\
\hline Asia emerging & 1.21 & 1.07 & 1.00 & 0.93 & 1.04 & 0.85 & 0.83 & 0.77 & 0.81 & 0.75 & 0.79 & 0.75 & 0.66 & 0.64 & 0.49 \\
\hline
\end{tabular}

Source: S\&P Capital IQ's own production according to data from the S\&P Capital IQ database

On emerging EU markets, after an initial fall from 1.4, the beta coefficient stabilized at the level of the "magic one" or just below it. The value of the beta coefficient also oscillates around one on developed Asian markets after a decline from an initial 1.4.

Perhaps the most interesting development is indicated by the beta coefficient in the case of investment banks in the USA, where the initial value of 0.65 in 2000, despite a sharp rise up to 1.8 in 2007 during the emerging economic and financial crisis, again decreases gradually to around 0.7 .

Table 8 | Beta Coefficients for Investment Banks - Centre Points

\begin{tabular}{|l|l|l|l|l|l|l|l|l|l|l|l|l|l|l|l|}
\hline $\begin{array}{l}\text { Investment } \\
\text { banks }\end{array}$ & $\mathbf{2 0 0 0}$ & $\mathbf{2 0 0 1}$ & $\mathbf{2 0 0 2}$ & $\mathbf{2 0 0 3}$ & $\mathbf{2 0 0 4}$ & $\mathbf{2 0 0 5}$ & $\mathbf{2 0 0 6}$ & $\mathbf{2 0 0 7}$ & $\mathbf{2 0 0 8}$ & $\mathbf{2 0 0 9}$ & $\mathbf{2 0 1 0}$ & $\mathbf{2 0 1 1}$ & $\mathbf{2 0 1 2}$ & $\mathbf{2 0 1 3}$ & $\mathbf{2 0 1 4}$ \\
\hline USA & 1.24 & 1.26 & 1.26 & 1.26 & 1.26 & 1.26 & 1.26 & 1.26 & 1.04 & 1.00 & 0.97 & 0.95 & 0.91 & 0.85 & 0.70 \\
\hline EU developed & 0.77 & 0.77 & 0.77 & 0.75 & 0.75 & 0.75 & 0.75 & 0.61 & 0.61 & 0.61 & 0.55 & 0.54 & 0.54 & 0.46 & 0.42 \\
\hline EU emerging & 1.14 & 1.14 & 1.14 & 1.14 & 1.14 & 1.14 & 1.14 & 1.14 & 1.14 & 1.14 & 0.97 & 0.93 & 0.93 & 0.94 & 0.94 \\
\hline Asia developed & 1.16 & 1.16 & 1.16 & 1.16 & 1.16 & 1.16 & 1.16 & 1.16 & 1.10 & 1.07 & 1.00 & 0.97 & 0.97 & 0.95 & 0.93 \\
\hline Asia emerging & 0.85 & 0.78 & 0.77 & 0.77 & 0.77 & 0.67 & 0.66 & 0.65 & 0.65 & 0.64 & 0.64 & 0.62 & 0.58 & 0.57 & 0.49 \\
\hline
\end{tabular}

Source: Own calculation.

Table 9 shows that for the allowed standard deviation of 0.15 , the development of beta coefficients has been stable in the case of Asia developed and Asia emerging since 2009 
and for EU developed and EU emerging since 2010. So, the use of the market value instead of the relatively complicated identification is possible only in these areas. It is not possible in the USA. The recommended values of the beta coefficient can be used at 0.6 on emerging Asian markets, 1 on emerging EU markets, 0.5 on EU developed and 1 on Asia developed.

Table 9 | Beta Coefficients for Investment Banks - Value of Width

\begin{tabular}{|l|l|l|l|l|l|l|l|l|l|l|l|l|l|l|l|}
\hline $\begin{array}{l}\text { Investment } \\
\text { banks }\end{array}$ & $\mathbf{2 0 0 0}$ & $\mathbf{2 0 0 1}$ & $\mathbf{2 0 0 2}$ & $\mathbf{2 0 0 3}$ & $\mathbf{2 0 0 4}$ & $\mathbf{2 0 0 5}$ & $\mathbf{2 0 0 6}$ & $\mathbf{2 0 0 7}$ & $\mathbf{2 0 0 8}$ & $\mathbf{2 0 0 9}$ & $\mathbf{2 0 1 0}$ & $\mathbf{2 0 1 1}$ & $\mathbf{2 0 1 2}$ & $\mathbf{2 0 1 3}$ & $\mathbf{2 0 1 4}$ \\
\hline USA & 0.58 & 0.56 & 0.56 & 0.56 & 0.56 & 0.56 & 0.56 & 0.56 & 0.34 & 0.30 & 0.27 & 0.25 & 0.21 & 0.15 & 0.00 \\
\hline EU developed & 0.35 & 0.35 & 0.35 & 0.33 & 0.33 & 0.33 & 0.33 & 0.19 & 0.19 & 0.19 & 0.13 & 0.12 & 0.12 & 0.04 & 0.00 \\
\hline EU emerging & 0.22 & 0.22 & 0.22 & 0.22 & 0.22 & 0.22 & 0.22 & 0.22 & 0.22 & 0.22 & 0.05 & 0.01 & 0.01 & 0.00 & 0.00 \\
\hline Asia developed & 0.23 & 0.23 & 0.23 & 0.23 & 0.23 & 0.23 & 0.23 & 0.23 & 0.17 & 0.14 & 0.07 & 0.04 & 0.04 & 0.02 & 0.00 \\
\hline Asia emerging & 0.36 & 0.29 & 0.28 & 0.28 & 0.28 & 0.18 & 0.17 & 0.16 & 0.16 & 0.15 & 0.15 & 0.13 & 0.09 & 0.08 & 0.00 \\
\hline
\end{tabular}

Source: Own calculation.

\subsection{Analysis of beta coefficient development for insurance companies}

Figure 3 | Beta Coefficient Development for Life Insurance Agencies

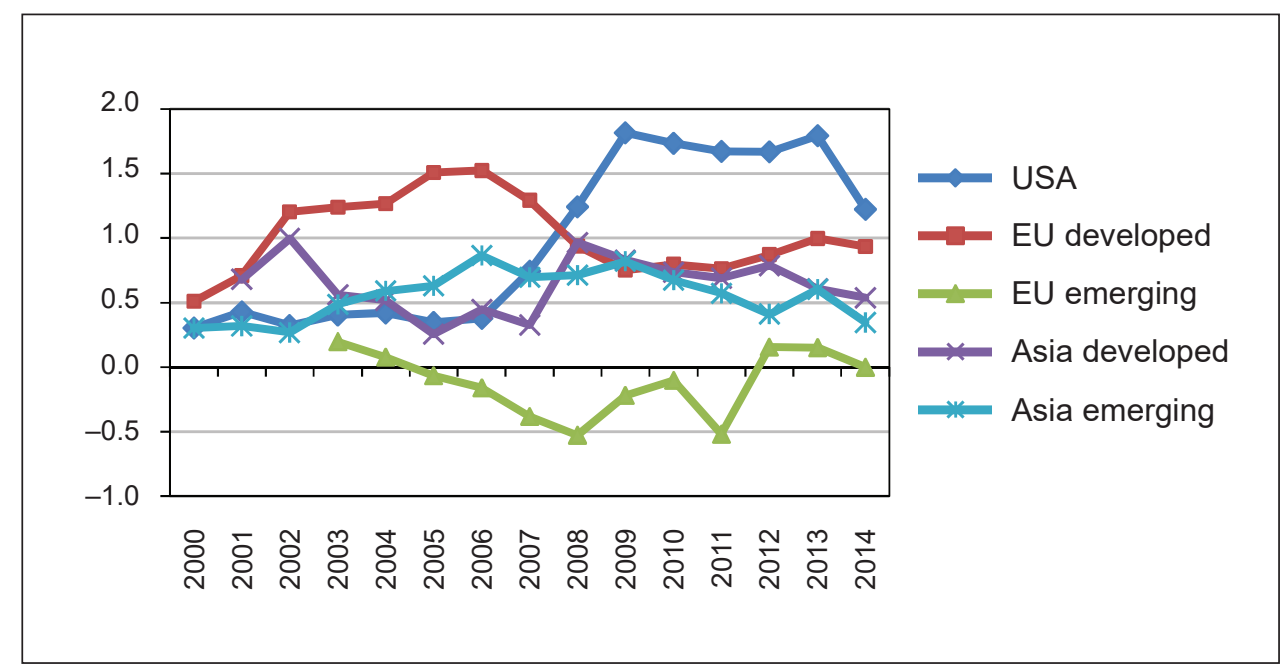

Source: S\&P Capital IQ's own production according to data from the S\&P Capital IQ database

In life insurance business, the volatility of the beta coefficient is relatively high and the value for EU emerging markets has been around zero in the last three years of the study 
period; in previous years, there was even a negative value at about -0.5 , which meant that the share prices of these insurance agencies went against the development of the stock market. It is then clear that this development cannot be reasonably used for valuation purposes in any way for this sector.

Table 10 | Beta Coefficient Development for Life Insurance Agencies

\begin{tabular}{|l|c|c|c|c|c|c|c|c|c|c|c|c|c|c|c|}
\hline $\begin{array}{l}\text { Life insurance } \\
\text { agencies }\end{array}$ & $\mathbf{2 0 0 0}$ & $\mathbf{2 0 0 1}$ & $\mathbf{2 0 0 2}$ & $\mathbf{2 0 0 3}$ & $\mathbf{2 0 0 4}$ & $\mathbf{2 0 0 5}$ & $\mathbf{2 0 0 6}$ & $\mathbf{2 0 0 7}$ & $\mathbf{2 0 0 8}$ & $\mathbf{2 0 0 9}$ & $\mathbf{2 0 1 0}$ & $\mathbf{2 0 1 1}$ & $\mathbf{2 0 1 2}$ & $\mathbf{2 0 1 3}$ & $\mathbf{2 0 1 4}$ \\
\hline USA & 0.30 & 0.43 & 0.32 & 0.41 & 0.42 & 0.35 & 0.38 & 0.74 & 1.24 & 1.82 & 1.73 & 1.67 & 1.67 & 1.79 & 1.22 \\
\hline EU developed & 0.51 & 0.71 & 1.20 & 1.24 & 1.27 & 1.51 & 1.53 & 1.29 & 0.94 & 0.75 & 0.80 & 0.76 & 0.87 & 1.00 & 0.93 \\
\hline EU emerging & - & - & - & 0.20 & 0.08 & -0.07 & -0.16 & -0.38 & -0.53 & -0.22 & -0.10 & -0.52 & 0.15 & 0.15 & 0.00 \\
\hline Asia developed & - & 0.68 & 1.00 & 0.56 & 0.52 & 0.25 & 0.45 & 0.33 & 0.97 & 0.83 & 0.74 & 0.69 & 0.79 & 0.61 & 0.54 \\
\hline Asia emerging & 0.30 & 0.32 & 0.27 & 0.49 & 0.59 & 0.63 & 0.87 & 0.70 & 0.71 & 0.82 & 0.67 & 0.57 & 0.41 & 0.60 & 0.35 \\
\hline
\end{tabular}

Source: S\&P Capital IQ's own production according to data from the S\&P Capital IQ database

By contrast, on the developed EU markets, after initial fluctuations within the range of 0.5 and 1.5 in recent years, the value has been relatively stabilized around one. The beta coefficients on emerging Asian markets have had a similar, relatively stable development, albeit at a much lower value oscillating at about 0.5 in recent years.

The highest values of the beta coefficient were recorded by US life insurance agencies. After initial relatively low values, an increase occurred during the economic and financial crisis up to a present value around 1.2. Unfortunately, this development makes any predictions of future developments of the beta coefficient very difficult.

\section{Table 11 | Beta Coefficients for Life Insurance Agencies - Centre Points}

\begin{tabular}{|l|r|r|r|r|r|r|r|r|r|r|r|r|r|r|r|}
\hline $\begin{array}{l}\text { Life insurance } \\
\text { agencies }\end{array}$ & $\mathbf{2 0 0 0}$ & $\mathbf{2 0 0 1}$ & $\mathbf{2 0 0 2}$ & $\mathbf{2 0 0 3}$ & $\mathbf{2 0 0 4}$ & $\mathbf{2 0 0 5}$ & $\mathbf{2 0 0 6}$ & $\mathbf{2 0 0 7}$ & $\mathbf{2 0 0 8}$ & $\mathbf{2 0 0 9}$ & $\mathbf{2 0 1 0}$ & $\mathbf{2 0 1 1}$ & $\mathbf{2 0 1 2}$ & $\mathbf{2 0 1 3}$ & $\mathbf{2 0 1 4}$ \\
\hline USA & 1.06 & 1.07 & 1.07 & 1.09 & 1.09 & 1.09 & 1.1 & 1.28 & 1.52 & 1.52 & 1.51 & 1.51 & 1.51 & 1.51 & 1.22 \\
\hline EU developed & 1.02 & 1.12 & 1.14 & 1.14 & 1.14 & 1.14 & 1.14 & 1.02 & 0.88 & 0.88 & 0.88 & 0.88 & 0.935 & 0.97 & 0.93 \\
\hline EU emerging & -0.17 & -0.17 & -0.17 & -0.17 & -0.19 & -0.19 & -0.19 & -0.19 & -0.19 & -0.19 & -0.19 & -0.19 & +0.08 & +0.08 & 0.00 \\
\hline $\begin{array}{l}\text { Asia } \\
\text { developed }\end{array}$ & 0.63 & 0.63 & 0.63 & 0.61 & 0.61 & 0.61 & 0.65 & 0.65 & 0.76 & 0.69 & 0.67 & 0.67 & 0.67 & 0.58 & 0.54 \\
\hline $\begin{array}{l}\text { Asia } \\
\text { emerging }\end{array}$ & 0.57 & 0.57 & 0.57 & 0.61 & 0.61 & 0.61 & 0.61 & 0.59 & 0.59 & 0.59 & 0.51 & 0.48 & 0.48 & 0.48 & 0.35 \\
\hline
\end{tabular}

Source: Own calculation.

Table 12 shows that for the allowed standard deviation of 0.15 , the development of beta coefficients has been stable in the case of EU developed since 2008 and in the case of Asia developed since 2009. So, the use of the market value instead of the relatively complicated 
beta coefficient identification is possible only in these two regions. The period of stable development in the other regions is relatively very short for confirmation of the beta coefficient stability. The recommended values of the beta coefficient can be used at 1 on EU developed and 0.6 on Asia developed.

Table 12 | Beta Coefficients for Life Insurance Agencies - Value of Width

\begin{tabular}{|l|l|l|l|l|l|l|l|l|l|l|l|l|l|l|l|}
\hline $\begin{array}{l}\text { Life insurance } \\
\text { agencies }\end{array}$ & $\mathbf{2 0 0 0}$ & $\mathbf{2 0 0 1}$ & $\mathbf{2 0 0 2}$ & $\mathbf{2 0 0 3}$ & $\mathbf{2 0 0 4}$ & $\mathbf{2 0 0 5}$ & $\mathbf{2 0 0 6}$ & $\mathbf{2 0 0 7}$ & $\mathbf{2 0 0 8}$ & $\mathbf{2 0 0 9}$ & $\mathbf{2 0 1 0}$ & $\mathbf{2 0 1 1}$ & $\mathbf{2 0 1 2}$ & $\mathbf{2 0 1 3}$ & $\mathbf{2 0 1 4}$ \\
\hline USA & 0.76 & 0.75 & 0.75 & 0.76 & 0.74 & 0.74 & 0.72 & 0.54 & 0.3 & 0.3 & 0.29 & 0.29 & 0.29 & 0.29 & 0.00 \\
\hline EU developed & 0.51 & 0.41 & 0.39 & 0.39 & 0.39 & 0.39 & 0.39 & 0.27 & 0.13 & 0.13 & 0.12 & 0.12 & 0.07 & 0.04 & 0.00 \\
\hline EU emerging & 0.37 & 0.37 & 0.37 & 0.37 & 0.34 & 0.34 & 0.34 & 0.34 & 0.34 & 0.34 & 0.34 & 0.34 & 0.08 & 0.08 & 0.00 \\
\hline $\begin{array}{l}\text { Asia } \\
\text { developed }\end{array}$ & 0.38 & 0.38 & 0.38 & 0.36 & 0.36 & 0.36 & 0.32 & 0.32 & 0.22 & 0.15 & 0.13 & 0.13 & 0.13 & 0.04 & 0.00 \\
\hline Asia emerging & 0.30 & 0.30 & 0.30 & 0.26 & 0.26 & 0.26 & 0.26 & 0.24 & 0.24 & 0.24 & 0.16 & 0.13 & 0.13 & 0.13 & 0.00 \\
\hline
\end{tabular}

Source: Own calculation.

\section{Conclusion}

The basic objective of this paper consisted in the analysis of the beta coefficients presented in different areas for three types of financial institutions: banks, investment banks and life insurance companies. In the final evaluation, we analyse whether the beta coefficient has a high tendency to reach number one and whether there is a relatively stabilized position of the beta coefficient for a certain period and a certain financial institution on a certain market and whether it is possible to avoid a relatively complicated process of beta coefficient identification in income valuation. A hypothesis could be stated that the beta coefficient values would be highly volatile, could be equal to one only in some specific cases and that the stable position of the beta coefficient is only in some periods for some specific financial institutions on some specific markets. There were also some data available concerning the real beta values from previous research. For that reason, an analysis of the five-year beta coefficient in the years 2000-2014 was performed for the USA, developed European, emerging European, developed Asian and emerging Asian regions to verify whether the identification of the beta coefficient does matter or whether it is better to accept the "magic one" or a certain stable position of the beta coefficient for an allowed deviation of 0.15 .

The hypothesis was confirmed, because the analysis clearly shows that the volatility of the beta coefficient in individual selected sectors and different regions is relatively high, but the tendency leads to some stabilization and for that reason it is possible to find some situations where the development is relatively stable. For the banks and the allowed deviation of 0.15 , the recommended values of the beta coefficient can be used at 0.6 on emerging Asian markets, 0.35 on USA markets, 0.6 on EU developed and 0.3 on Asia developed. For investment banks and for the allowed deviation of 0.15 , the recommended values of the beta coefficient can be used at 0.6 on emerging Asia markets, 1 on emerging 
EU markets, 0.5 on EU developed and 1 on Asia developed. For life insurance agencies and for the allowed deviation of 0.15 , the recommended values of the beta coefficient can be used at 1 on EU developed and 0.6 on Asia developed. The "magic one" can be used only in two cases and, for that reason, its importance is decreasing very strongly.

The comparison with Damodaran (2009) is also interesting: Table 1, in which the substantially higher beta coefficient values are given for all regions and for the commercial and investment banking sectors. Also, data from the S\&P Capital IQ database confirm that in the time series, a decline in the coefficients mostly occurs across regions regardless of the types of banks, which also supports the findings by King (2009). In the case of life insurance data according to Damodaran (2009; Table 1), only in the US region are they getting closer to the data by S\&P Capital IQ; even here (the Czech Republic) the data are at least one tenth lower. However, Equation 5 can potentially be exploited in this region.

The above empirical study also shows the interesting fact that the most stable values are shown by the emerging Asian markets for all the examined segments. On the contrary, the highest instability and volatility is shown by the emerging European markets. Given the above facts, when valuing a financial institution, the beta coefficient should not automatically be selected to be equal to one, but it should be estimated according to the analogy method with due regard to differences between the valuated financial institution and comparable financial institutions (at least in terms of the region and the nature of services provided). It is more practical when estimating the beta coefficient to work directly with the indebted beta using the analogy method, i.e., taking over the beta from comparable institutions in their given debt. This simplification is also supported by the fact that different types of financial institutions tend to gain a similar capital structure through regulation. This idea to work with indebted beta using the analogy method appears not only in Damodaran (2002), but it is also shared by Koller (2005). He does not recommend adjusting the beta for different levels of debt with the comment that the profit volatility and, subsequently, the risk in financial institutions are affected by the mismatch of assets rather than by indebtedness. The most important contribution to financial theory and financial practice is the fact that besides relatively complicated methods for identification of the beta coefficient, it is possible to use, to a limited extent, some of the recommended values mentioned above for some financial institutions and for some specific markets and that values of the beta coefficient are relatively decreasing with volatility limitation. The value of the beta equal to one considered as a simplification in the recent literature is actually refused with the above exceptions.

\section{References}

Allen, P. R., Wilhelm, W. J. (1988). The Impact of the 1980 Depository Institutions Deregulation and Monetary Control Act on Market Value and Risk: Evidence from the Capital Markets. Journal of Money, Credit and Banking, 20(3), 364-380, https://doi.org/10.2307/1992262

Brooks, R. D., Faff, R. W., Yew, K. H. (1997). A New Test of the Relationship between Regulatory Change in Financial Markets and the Stability of Beta Risk of Depository Institutions. Journal of Banking and Finance, 21(2), 197-219, https://doi.org/10.1016/ s0378-4266(96)00034-9 
Damodaran, A. (2001). The Dark Side of Valuation. New York: Prentice-Hall, Inc.

Damodaran, A. (2002). Investment Valuation. New York: John Wiley \& Sons.

Damodaran, A. (2009). Valuing Financial Service Firms. [Retrieved 2016-01-10] Available at: http://pages.stern.nyu.edu/ adamodar

Blume, M. (1975). Betas and Their Regression Tendencies. Journal of Finance, 30(3), 785-795, https://doi.org/10.1111/j.1540-6261.1975.tb01850.x

DATABÁZE S\&P Capital IQ.

Dickens, R., Philippatos, G. (1994). The Impact of Market Contestability on the Systematic Risk of US Bank Stocks, Applied Financial Economics, 4(5), 315-322, https://doi. org/10.1080/758536469

Hazel, J. J. (1996). The Bank Valuation Handbook. New York: Irwin Publications. ISBN 978-1557387950.

Hejduková, M. (2010). Výnosové metody oceňování komerčních pojištoven. Oceňování, 3(3), 16-26.

Hrdý, M. (2012). Problematika diskontní úrokové míry při oceňování bank a dalších finančních institucí. Oceňování, 5(3), 14-26.

Hrdý, M. (2005). Oceňování finančních institucí. Praha: Grada Publishing.

Hrdý, M. (2005). Problematika diskontní úrokové míry při výnosovém oceňování finančních institucí. In Sborník z mezinárodní konference Finance a účetnictví ve vědě, výuce a praxi. UTB Zlín, (pp. 62-63).

Chen, R.-R., Chidambaran, N.K., Imerman, M. B., Sopranzetti, B. J. (2014). Liquidity, Leverage, and Lehman: A Structural Analysis of Financial Institutions in Crisis. Journal of Banking \& Finance, 45, 117-139, https://doi.org/10.1016/j.jbankfin.2014.04.018

Jähnchen, S. (2009). Kapitalkosten von Versicherungsunternehmen. Wiesbaden: Gabler. ISBN 978-3-8349-1299-2.

King, M. R. (2009). The Cost of Equity for Global Banks: a CAPM Perspective from 1990 to 2009. BIS Quarterly Review September.

Koller, T., Goedhart, M., Wessels, D. (2005). Valuation. Measuring and Managing the Value of Companies. New York: John Wiley \& Sons.

Miller, W. D. (1995). Commercial Banks Valuation. USA, New York: John and Sons, Inc.

Mařík, M. et al. (2007). Metody oceňování podniku. Proces ocenění, základní metody a postupy. 2. vydání, Praha: Ekopress, s.r.o. ISBN 978-80-86929-32-3.

Mařík, M. et al. (2011). Metody oceňování podniku pro pokročilé. 1. vyd. Praha: Ekopress s.r.o. ISBN 978-80-86929-80-4.

Pláničková, M. (2014). Modifikace výnosových metod pro účely oceňování komerčních pojištoven. Oceňování, 7(4), 80-97.

Rezaee, Z. (2001). Financial Institutions, Valuations, Mergers and Acquisition. USA, New York: Wiley John and Sons.

Stever, R. (2007). Bank Size, Credit and the Sources of Bank Market Risk. BIS. Working Papers No 238, Basel, https://doi.org/10.2139/ssrn.890658 